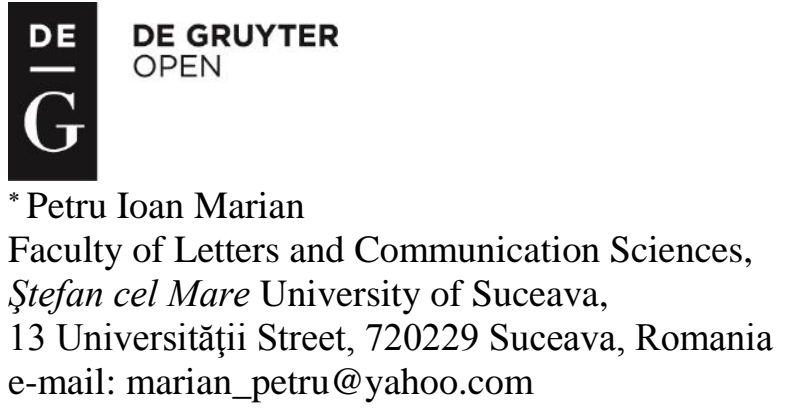

\title{
THE LANGUAGE OF ROMANIAN POLITICS: REIFYING THE OTHER
}

\begin{abstract}
The dominant ideology of a society seems to possess the means to infiltrate an individual's conscience with relative ease. From the perspective of the functions of language, we intend to investigate those fundamental characteristics of the ideological discourse that reify the left-right dichotomy in Romanian politics.
\end{abstract}

Keywords: ideology, political discourse, the functions of language

Language is a conclusive factor in the shaping of reality and a disputed resource of society. Having a hold of a society's linguistic resources may guarantee, for instance, the success of a political project. Language's link to power, thus to those situations in which power is transacted or relations of authority between individuals or groups of individuals are negotiated, leave a mark on the structure of language. Ernesto Laclau defined the ideological discourse in the following terms:

The ideological would consist of those discursive forms through which a society tries to institute itself as such on the basis of closure, of the fixation of meaning, of the non-recognition of the infinite play of differences. The ideological would be the will to 'totality' of any totalizing discourse. (Laclau, 1991: 27)

We are interested in investigating, from the perspective of the functions of language, what structural characteristics of the ideological discourse participate in this process of closure of meaning. A major importance in understanding the investigated phenomenon is given to linguist Olivier Reboul's work (Reboul, 1986). In "Language and ideology", he offers an analysis from the perspective of the code's language functions on the basis of which the ideology functions at the level of discourse. Using Jakobson's pattern, Reboul contrives an analysis model of the ideological discourse in which the general functions of language are subordinate to ideology's primordial function of sustaining power and which follows the manner in which each of the six functions of language are shaped up by other functions.

Employing Reboul's model of analysis we intend to highlight some reiterations of referential functions of the ideological language in the Romanian political field.

The referential or denotative function is the one which guides the message to reality, governing in objective communication. In its practise of legitimising authority, the ideological discourse entails a referential component. Striving for truth, the ideological discourse backs up its arguments with factual information.

The processes defining of the referential function of the ideological discourse are: A) the creation of the referent and B) the meaning slips.

* Dr Petru Ioan Marian is Instructor of Communication Studies at Stefan cel Mare University of Suceava, Romania. He is working in the fields of mass-media research, communication sciences, and cultural studies. 
A) Aware of the fact that the referent does not simply reflect the natural world, but is, for its part, a figment of the cultural world, ideologies exploit the relativity of the reference through the mechanisms: a) of the "objectifying address", b) of the "blending process", c) of "assumption" and d) of the "false causality". (Reboul, 1986: 57)

a) By objectifying address, Reboul apprehends the device though which ideologies create the referent by no more than naming. At a time when in the rise of the Romanian democracy there was talk about "terrorists", "hooligan elements" as some tangible threats to the social order, the referent alluded to a mythical and ephemeral or profoundly distorted reality. In this case, the metalingual function conceals the abusive use of the referential function, switching from words to objects.

b) Another device from the referential creation class is the "blending process", which consists in using a reductive term to assimilate different realities in an abusive manner. Words such as "totalitarian" or "democracy" can cover completely distinct realities, according to the ideology of those who use them in the speech:

USL leads the country towards the Soviet totalitarian regime, justice is their primary aim ${ }^{1}$.

Băsescu's totalitarian regime and repressive structures (PARCHET, DNA, SRI, SIE, CCR, SPP, etc) ${ }^{2}$.

The blending process functions as a combination of three functions: metalingual, phatic and referential: "attributing the same name to different realities (the metalingual function) leads to their identification (the referential function), eliminating the terms expressing differences, thus limiting the domain of the discourse (the phatic function)"(Reboul, 1986: 60).

c) The ideological discourse may generate the referent through "assumption", defined as an element not stated in the statement, but which must be presumed for the statement to gain meaning. The ideological discourse prefers the indirect speech acts and the implicit, assumption being pursued to the detriment of assertions:

We voted for an uncorrupted Bucharest, for a new political class ${ }^{3}$.

The previous statement contains explicit information as well as a series of assumptions: there exists an obsolete political class that has proven its corruption, the adversary political class and a "new political class" defined by antinomy, which deserves to be voted.

Reboul considers that assumption is more efficient than direct articulation, for the receiver has the impression that he is free. Assumptions put forth by the ideological discourse establish a judicial power of phatic nature, determining people to answer implicit questions of their own free will. Assumption also makes use of the metalingual function to create a referent or a frame of reference.

d) The ideological discourse is not only in charge of creating referents, but also of creating reasons/grounds, explicatory links between events. Ideology's function is to explain evil (crisis, unemployment, poverty, wars), ascribing blame exclusively to political adversaries. Assigning responsibility is generated by the "false causality" mechanism, which frequently takes the shape of the extremely broad term "them":

They had the power to cut salaries... now you have the power to take their power. Vote! They had the power to mock the old... now you have the power to take their power. Vote! ${ }^{4}$

\footnotetext{
${ }^{1}$ USL leads the country to a totalitarian regime (USL duce tara spre regimul totalitar), accessed 10.10.2014, available at http://mihael-duca.blogspot.ro/2012/07/usl-duce-tara-spre-regimul-totalitar-de.html.

2 Traian Basescu's totalitarian regime and repressive structures (Regimul totalitar și structurile represive ale lui Traian Basescu), accessed 10.10.2014, available at https://octavpelin.wordpress.com/2013/07/04/regimultotalitar-si-structurile-represive-ale-lui-traian-basescucomisarii-politici-din-ani-50/.

${ }^{3}$ My translation of “Am votat pentru un Bucureşti necorupt, pentru o nouă clasă politică”. Nicușor Dan's Facebook page, accessed 10.06.2016, available at https://ro ro.facebook.com/nicusordan.pentrubucuresti/.

4 Campaign slogans in Bucharest [Mesaje de campanie in Bucuresti], accessed 16.06.2015, available at http://www.paginademedia.ro/2012/07/foto-galerie-mesajele-de-campanie-in-bucuresti-afisele-impotrivasuspendarii-aproape-invizibile.
} 
A form of grammatical marking of the relationships of power and creation of the referent is the usage of personal pronoun we possessing an exclusive meaning, as opposed to the personal pronoun we bearing an inclusive meaning (Fairclough, 1989: 128). The principles of exclusion and inclusion assumed by the pronominal self-reference reflect the partisan strategies of power in the political process. In the first instance, the pronoun we includes the speaker and the group they belong to, but it excludes the receiver, while the second meaning of the word employs the receiver in its referential field:

We reassess the content and the effect of the current structural transformation from the perspective of these long-term changes. This is our chance, one we are not allowed to lose! ${ }^{5}$

In the example above, pronoun we changes its reference from the first sentence to the following statement. While the first meaning is rather institutional, we being a substitute for the political instance - the party analysing the course of action and taking responsibility for decisions (we, the party, reassess), the second implication of the pronoun is a collective one. Bearing the second meaning, inserted in the verbal desinence, the pronoun "we" designates a "compact collective subject" (us all, the citizens, the people, we are not allowed to lose), "an amplified and diffuse person" (Maingueneau, 2007: 151). The process of embedment of the civil instance into the deictic "we" category is illustrated below:

We are facing a fundamental choice today: either we maintain the welfare state, or we rebuild the state from the ground, on the principles of the liberal state. ${ }^{6}$

If in a casual conversation the inclusive form of the pronoun we is a sign of solidarity, in the political discourse, where a high amount of ambiguity hovers about the identity of the action agents, this usage can be a form of authority dissimulation by alluring the receiver in the verb's action area.

It is necessary that we reconsider the work value in the development of society, that we fight unsparingly in order to surmount difficulties of the economical and social crisis. One does not fight poverty with words and polite speeches, but with practical action, with intelligent work and effort. We will live better only as soon as we will organise ourselves and work better. ${ }^{7}$

In the paragraph above the occurrences of we are semantically ambiguous due to their referents fluctuating between the meanings of us, all citizens and us, the power. The verbs' prescriptive character mixed with the dilatation of the deictic particle's sense on a collective level, where the speaker pretends to speak for the group, are forms of power manifestation on a declarative level.

With an exclusive denotation, we in the ideological discourse does not appear as a deictic element: "he is here to oppose, implicitly or explicitly, the pronoun "they", which brands the reaction forces; it is symmetrical to the latter. It represents a third ... person" (Thom, 1993: 43).

To us it is vital for democracy to be not only a principle of political establishment, but also a factor that would operate in the structuring of the civile society, the economical life and community identity. If democracy would be restricted to the political sphere, to the elective moment and the people's right to free speech and association, it would mean that competitive mechanisms and money dictatorship would act exclusively in the social-economical life sphere. ${ }^{8}$

\footnotetext{
5 The Social Democratic Party's Program (Programul Partidului Social Democrat), accessed on 11.10.2013, available

https://www.google.ro/?gws_rd=cr,ssl\&ei=oCVuVOeOD5TjaszwgdgP\#q=PARTIDUL+SOCIAL+DEMOCRA $\mathrm{T}+$ program+politic.

6 The National Liberal Party's Program [Programul Partidului Naţional Liberal], accessed on 11.10.2013, available at http://www.pnl.ro/pagina/statul-liberal-a-doua-modernizare-a-romaniei.

7 The Social Democrat Party's Program (Programul Partidului Social Democrat), accessed on 11.10.2013, available

https://www.google.ro/?gws_rd=cr,ssl\&ei=oCVuVOeOD5TjaszwgdgP\#q=PARTIDUL+SOCIAL+DEMOCRA T+program+politic.

8 The Social Democratic Party's Program [Programul Partidului Social Democrat], accessed on 11.10.2013, available 
The 'we' in the previous example alludes to the Social Democratic Party, i.e. to the party's program. It exposes the social, economical and political contrast between two sides. The speech is engineered upon a binary rhetoric that opposes the positive values of social democracy: the democratization of society stands in opposition to the negative values of liberalism: the social and economical life governed by competitive mechanisms and money-making.

The ideological discourse operates in reverse as well, aiming to dodging causality connections. To Linguistic Criticism, the agent-action structure, which makes a distinction between those who realise actions and those who suffer from them, is important because it betrays an ideological function in the speech of power: Linguistic Criticism is convinced that choosing a certain transitive phrase in sentences leads to the outlining of a certain view upon world. The consequences of this choice are part of reality's linguistic formation, contributing to the creation of relationships and power differences. (Fowler \& Kress, 1979) thus we ascertain the ideological discourse's preference to passive and impersonal constructions, which avoid the agent of action:

The state must not be seen as an objective as such anymore, costly and dull, its expansion must be retained and any form of aggression against the civil society, against its own citizens, must be eliminated.

The transition themes have been, prioritarily, debated under their political and economical aspects. It has been, however, passed over the fact that the transition is, in fact, a profoundly cultural process. ${ }^{9}$

Although progress has been made and the Romanian society is not the same as in 1989, passing to

a new type of society and civilisation does not go without a hitch.

...special attention has been given to the stage in which justice reforms are. ${ }^{10}$

The passivation tool allows for controlling the speech's thematic priorities. Due to the grammatical subject's position bearing the information of the act's responsibility, the passive impersonal style permits a new agent to be placed as subject, functioning as the essential theme of the sentence and the real agent to sink into anonymity.

B) Using the "meaning slips" mechanism, the ideological discourse may attribute a real referent another meaning than the established one. The communist ideology marked the alterity composed of opponents and dissidents with the phrase "enemies of the people" and the regime's collaborators in the terms "labour people". The political prison was seen as an honourable institution for "re-education" or "solitary deprivation" of antirevolutionary elements, and the "popular democracy" could coexist, in a totally unsurprising manner, with the "proletarian dictatorship".

The vocabulary reflects the priorities of a linguistic community. Abstract or highly semantically multivalent words such as "freedom" are referentially fastened in context through ideological occurrences. To the liberal doctrine, the freedom of speech, free association and movement are semantically subordinate to the freedom of possession. By making the freedom of possession and social success equal, liberalism exonerates society of the responsibility of personal fail teaching us that an individual's greatest liberty is the one to gather capital. Individual freedom is apprehended by liberals as enterprising or contractual liberty, the liberty to private initiative, to capital market, to price fixing, to job market, to movement of goods, and by socialists as freedom of thought, conscience and expression.

https://www.google.ro/?gws_rd=cr,ssl\&ei=oCVuVOeOD5TjaszwgdgP\#q=PARTIDUL+SOCIAL+DEMOCRA T+program+politic.

9 The National Liberal Party's Program [Programul Partidului Naţional Liberal], accessed on 11.10.2013, available at http://www.pnl.ro/pagina/statul-liberal-a-doua-modernizare-a-romaniei.

10 The Social Democratic Party's Program [Programul Partidului Social Democrat], accessed 11.10.2013, available

at https://www.google.ro/?gws_rd=cr,ssl\&ei=oCVuVOeOD5TjaszwgdgP\#q=PARTIDUL+SOCIAL+DEMOCRA T+program+politic. 
Although started two decades ago, the offensive for property and economical freedom is not ended. ${ }^{11}$

PSD supports the freedom of thought and religion. ${ }^{12}$

Meaning slips are obtained through a) dichotomies and b) litotes. (Reboul, 1986: 66)

a) Dichotomies function by placing two terms in opposition, valorizing one pole in order to disqualify the other: "the free world vs. totalitarian countries", advanced liberalism vs. populist socialism", "reformatory forces vs. retrograde forces".

The left and the right each come with their own vision of state structure. Qualifiers "social" and "liberal" attached to nominal phrases function as exclusivist linguistic marks of ideological affiliation. The polemic character of the political speech makes it so that the two projects of organisation of the state define themselves adversatively. The signification of this definition through contrast is capitalizing on its own ideological identity and disqualifying the antagonistic view by use of pejorative qualifiers, according to a simplifying Manichean logic. The terms of the comparison appear thus as irreconcilable:

We are facing a fundamental choice today: either we maintain the welfare state, or we rebuild the state from the ground, on the principles of the liberal state. ${ }^{13}$

The semantic gap between partial synonyms "workers" - "employees", "income classes" "workforce" is subtle, denoting a different ideological engagement. According to leftist ideology, it is completely natural for labourers to have a class conscience of those who receive a salary, as it is habitual, while the right believes it is fair that the individual rent their workforce for productivity purposes.

Similarly, the words "rrom" and "țigan" have approximately the same referent, but two opposite meanings - a positive one, the other negative. The first involves acknowledgement to the way in which the identity of the ethnic group is advantageously self-defined by its members, while the latter is the manner in which the exogroup disparagingly nominates the minority. Dismissing one of these terms would be equivalent to erasing an entire referential sector, whose right to existence is denied.

b) Another form of referring to particular subjects is the use of litotes. The litotes exorcises the element that questions the legitimacy of power, being a form of symbolic violence which consists in saying that the enemy does not exist. Not offering the most accurate information, the ideological discourse does violence to O. Ducrot's rhetorical principle (Ducrot, 1983). The litotes acts by disqualifying or minimizing the enemy: "a clan", "a camarilla", "a handful of instigators":

Băsescu wants to keep a kleptomaniac camarilla on staff. ${ }^{14}$

The organised crime gang, Senat section from the Romanian Parliament, has kim-ir-sen-ist endeavours regarding the freedom of speech. ${ }^{15}$

If the ideological discourse saves the disqualifying litotes for describing the opponent, when it designates power it uses the hyperbolic phrases: "the masses", "the will of the people":

11 The National Liberal Party’s Program [Programul Partidului Naţional Liberal, accessed on 11.10.2013, available at http://www.pnl.ro/pagina/statul-liberal-a-doua-modernizare-a-romaniei.

12 The Social Democratic Party's Program (Programul Partidului Social Democrat), accessed on 11.10.2013, available https://www.google.ro/?gws_rd=cr,ssl\&ei=oCVuVOeOD5TjaszwgdgP\#q=PARTIDUL+SOCIAL+DEMOCRA T+program+politic.

${ }^{13}$ The National Liberal Party’s Program (Programul Partidului Naţional Liberal), accessed 11.10.2013, available at http://www.pnl.ro/pagina/statul-liberal-a-doua-modernizare-a-romaniei.

14 Orban: Băsescu wants to keep a kleptomaniac camarilla on staff, accessed on 16.06.2015, available at http://www.ziare.com/basescu/presedinte/orban-basescu-vrea-sa-mentina-o-camarila-cleptomana-la-butoane931751.

${ }^{15}$ The Parliament, a crime group [Parlamentul, grup infracţional], accessed on 10.01.2016, available at https://www.google.ro/?ion=1\&espv=2\#q=parlamentul+grup+infractional\&start=10. 
The revision of the Constitution is not concluded and there is still a chance for the Parliament to return to honouring the will of the people, there is also the possibility for the Constitutional Court to dismiss a revision law that takes the will of the people into consideration. ${ }^{16}$

The analysis pattern of the ideological discourse designed by Reboul connects interindividual communication to the political one, projecting the functions of language into the area of discursivity and political action. We can conclude that an ideology id structurally linked to the terms and mechanisms that express it, that ideological thinking is inseperable from the ideological language and that this relationships has consequences on the political behaviour of human groups. If we accept the hypothesis that language conditions thinking, a clichéd instrumental language results in a unidimensional thinking which is not capable of finding the conceptual and linguistic resources to express any form of opposition.

\section{Works Cited}

Ducrot, O., Anscombre, J.-C., 1983, L'argumentation dans la langue, Liége: Mardaga.

Fairclough, N., 1989, Language and power, New York: Longman Group.

Fowler, R., Kress, G., 1979, "Critical Linguistics", in Fowler, R. et al., Language and Control, London, Boston: Routledge \& K. Paul.

Laclau, E., 1991, "The impossibility of society". In Ideology and power in the age of Lenin in ruins, Canadian Journal of Political and Social Theory, volume 15, vol. 1, 2 \& 3, Montreal: Concordia University.

Maingueneau, D., 2007, Analiza textelor de comunicare, Iaşi: Institutul European.

Reboul, O., 1980, Langage et idéologie, Paris: Presses Universitaires de France.

Thom, F., 1993, Limba de lemn, Bucureşti: Humanitas.

Primary Sources:

“Campaign slogans in Bucharest" [Mesaje de campanie in Bucuresti], accessed on 16.06.2015, available at http://www.paginademedia.ro/2012/07/foto-galerie-mesajele-de-campanie-in-bucuresti-afiseleimpotriva-suspendarii-aproape-invizibile.

Nicuşor Dan's Facebook page, accessed on 10.06.2016, available at https://roro.facebook.com/nicusordan.pentrubucuresti/.

“Orban: Băsescu wants to keep a kleptomaniac camarilla on staff”, accessed on 16.06.2015, available at http://www.ziare.com/basescu/presedinte/orban-basescu-vrea-sa-mentina-o-camarila-cleptomana-labutoane-931751.

“The National Liberal Party's Programme” [Programul Partidului Naţional Liberal], accessed on 11.10.2013, available at http://www.pnl.ro/pagina/statul-liberal-a-doua-modernizare-a-romaniei.

"The Parliament, a crime group" [Parlamentul, grup infracţional], accessed on 10.01.2016, available at https://www.google.ro/?ion=1\&espv=2\#q=parlamentul+grup+infractional\&start=10.

“The president's statement" [Declarație președinte], accessed on 16.16.2015, available at http://www.mediafax.ro/politic/basescu-am-declansat-procedura-pentru-un-nou-referendum-pentruunicameral-si-300-de-parlamentari-declaratiile-presedintelui-10956481

“The Social Democratic Party's Program” [Programul Partidului Social Democrat], accessed on 11.10.2013, available https://www.google.ro/?gws_rd=cr,ssl\&ei=oCVuVOeOD5TjaszwgdgP\#q=PARTIDUL+SOCIAL+DE MOCRAT+program+politic.

"Traian Basescu's totalitarian regime and repressive structures", accessed on 10.10.2014, available at https://octavpelin.wordpress.com/2013/07/04/regimul-totalitar-si-structurile-represive-ale-lui-traianbasescucomisarii-politici-din-ani-50/.

"USL leads the country to a totalitarian regime", accessed on 10.10 .2014 , available at http://mihaelduca.blogspot.ro/2012/07/usl-duce-tara-spre-regimul-totalitar-de.html.

16 The president's statement [Declarație președinte], accessed on 16.16.2015, available at http://www.mediafax.ro/politic/basescu-am-declansat-procedura-pentru-un-nou-referendum-pentru-unicameralsi-300-de-parlamentari-declaratiile-presedintelui-10956481. 